Юркова О. І., ад юнкт Наиіонального університету оборони Украӥни ім. I. Черняховського https://orcid.org/0000-0002-5679-6584

\title{
ТЕОРЕТИЧНИЙ АНАЛІЗ ОСНОВНИХ КОНЦЕПЦІЙ ГОТОВНОСТІ ОСОБИСТОСТІ ДО ПРОФЕСІЙНОЇ ДІЯЛЬНОСТІ
}

У статті висвітлено теоретичні підходи до аналізу феномену готовності особистості до професійної діяльності. Наведено аналітичний огляд иьього поняття різними вченими. Проаналізовано поняття готовності військовослужбовиів до дій в екстремальних умовах.

Встановлено, щу психологічна готовність військових залежать від особливостей нервової системи, життєвого досвіду, професійних знань, навичок, мотиваиї та інших особливостей індивіда.

Ключові слова: психологічна готовність; функиіональний підхід; особистісний підхід; військовослужбовиі; військова діяльність.

Постановка проблеми. За своїми вихідними характеристиками професійна діяльність військовослужбовців пов'язана 3 постійною загрозою для життя і здоров'я, стресом, ризиком, негативними емоційними станами, великими психофізичними навантаженнями. Захист державних інтересів та безпеки країни, в свою чергу, висуває підвищені вимоги до стану психічного здоров'я та збільшуе соціальну значущість професії військовослужбовця. Війна на сході України посилила вимоги до професійної $\mathrm{i}$ особистісної відповідальності за результати та наслідки діяльності військовослужбовців Збройних Сил України. Необхідною умовою успішного початку, виконання та завершення будь-якої діяльності $\epsilon$ готовність до іï здійснення.

Аналіз останніх досліджень та публікацій. Природно, що феномен психологічної готовності особистості до діяльності завжди мав великий інтерес. Особливого значення готовність набуває в контексті якісного виконання завдань, підвищення іï успішності, використання сили та можливостей особистості у невизначених та екстремальних умовах. Значний вклад у дослідження проблеми психологічної готовності до діяльності, як у загальнотеоретичному, так і в прикладному плані, внесли відомі вчені в галузі військової психології (Мул С., Осьодло В., Потапчук С., Сафін О., Столяренко А., Хміляр О., Ягупов В.), психології спорту (Деркач А., Пуні А., Хуртенко О.), психології управління (Барко В., Карамушка Л., Філь О.), психології праці (Клімов Є., Моляко В., Платонов К.) та інженерної психології (Ананьєв Б., Леонтьєв О., Ломов Б., Смирнов Б.). Зрозуміло, що різні види діяльності мають свої особливості психологічної готовності, проте більшість науковців відмічають існування загальних характеристик психологічної готовності. Будь-яка діяльність починається із психологічної готовності, яка $\epsilon$ універсальною передумовою ефективності та відіграє важливу роль від початку та до іiі завершення.

Мета статті: теоретичний аналіз основних концепцій готовності особистості до професійної діяльності.

Методи дослідження: теоретичний аналіз, узагальнення.

Виклад основного матеріалу:

Стан психологічної готовності сприяе якісно виконувати свої функціональні обов'язки, застосовувати знання, досвід, особисті якості, зберігати самоконтроль i швидко орієнтуватися при зміні обставин.

Юрченко В. описав психологічні стани виділивши чотири структурні рівні: соціально-психологічний, психічний, психофізіологічний i фізіологічний. Експериментальні дослідження підтверджують важливу роль у структурі стану соціально-психологічного та психічного рівнів. Кожен 3 цих рівнів має суб'єктивні й об'єктивні характеристики станів [14].

Психологічна готовність це система психологічних i психофізіологічних характеристик суб'єкта, що забезпечують успішність і результативність певних дій та діяльності. Тому вивчати проблему готовності до професійної діяльності неможливо без вивчення самої діяльності та iï специфіки.

3 професійної точки зору військовопрофесійна діяльність відрізняється від усіх інших видів трудової діяльності завданнями, засобами, способами і умовами виконання завдань. У воєнний час вона спрямована на 


\section{Питання психології}

знищення супротивника, а у мирний - на підтримання постійної бойової готовності. Таким чином, військовій діяльності притаманні в першу чергу виконання завдань в бойових умовах (екстремальних та особливих умовах), труднощі служби, велике навантаження фізичних і психічних сил, вкрай обмежений час для виконання завдань, регламентований побут.

Діяльність військовослужбовця Збройних Сил України $\epsilon$ специфічною 3 огляду на психологічні, соціальні, моральні та інші аспекти пов'язані 3 необхідністю швидко ухвалювати самостійні, виважені та обгрунтовані рішення як в умовах повсякденної діяльності так i під час виконання бойових завдань. Іншим специфічним аспектом військової діяльності $\epsilon$ наявність високого рівня професійної та психологічної підготовки, котра забезпечує психологічну готовності військовослужбовця до виконання завдань, які передбачають використання зброї та фізичної сили, ризик втрати життя та здоров'я. Але навіть у фахівців, що мають однакові показники професійної підготовки, результати службової діяльності можуть бути різні, через відмінності в стані психологічної готовності. Вчорашні звичні завдання які виконувались 3 високою ефективністю, в бойових умовах не вдається здійснити в повній мірі. Це прояв недостатньої підготовки воїна в психологічному відношенні.

Як зазначає Бойко О., професія «офіщер» $€$ однією із найскладніших професій людського суспільства, тому що вимагає від iï суб'єкта здатності з високою ефективністю вирішувати професійні завдання в бойових (екстремальних, особливих) умовах, які пов'язані з ризиком для життя, обмеженим часом та прийняттям рішення, високим рівнем відповідальності як за свої дії, так і за дії підлеглих.

Поняття «екстремальність» часто вживається для позначення будь-яких умов, які породжують стрес. Особливі умови відрізняються від стресогенних або екстремальних меншою інтенсивністю i специфічної спрямованістю на діяльність.

В своїх працях Тимченко А. визначає залежність поведінки в стресі від ступеня значущості ситуації та від психологічної структури особистості (ставлення людини до труднощів у роботі, успіху і невдачі, співвідношення рівня домагань і реальних можливостей, впевненості і непевності у своїх силах, спрямованості особистості).
Відзначено, що людина реагує не тільки на дійсно існуючу небезпеку, але також на загрози і символи небезпеки, які пов'язані з переживаннями у минулому. Саме це i дозволяє їй знаходитися в стані готовності, пускати в хід свої захисні механізми за той незначний відрізок часу, що відокремлює виникнення стресу від прояву його аспектів. Ця готовність $\epsilon$ не тільки наслідком багатьох соціально-економічних впливів і емоційних конфліктів, але і являє собою необхідну умову виживання [12].

Лебедев В., Смирнов Б., Довгополов $€$. сходяться на думці, що поняття «особливі умови» діяльності може бути застосовано до тих ситуацій, коли діяльність пов'язана 3 епізодичною дією екстремальних чинників або виникнення екстремальних ситуацій, а екстремальні умови діяльності пов'язані 3 постійною дією цих чинників [11]. Вважається, що екстремальні ситуації в діяльності військовослужбовця виникають тоді коли $є$ реальна загроза життю та здоров'ю особового складу, використання зброї для власного захисту та оборони державних інтересів. Найважливішими елементами структури застосування зброї вважаються здатність військовослужбовця швидко і об'єктивно оцінити обставини застосування зброї в складній ситуації i психологічна готовність до їі використання.

Велику увагу вивченню психічних станів готовності та працездатності приділив Левітов М. Він класифікує психологічні стани за аналогією з поділом психологічних процесів. Автор розрізняє стани в залежності від того, які психічні функції переважають: пізнавальні, вольові чи емоційні.

Одним 3 головних станів Левітов М. виокремлює стан готовності до діяльності. Вчений виокремлює довготривалу готовність, яка ним трактується як придатність чи непридатність людини до виконання певної роботи і тимчасовий стан готовності, який називає «передстартовим станом». Левітов М. відзначає три види передстартового стану: звичайний, підвищений i понижений [4]. Прикладом звичайного стану може бути готовність, що існуе перед початком звичної, добре знайомої роботи, яка на даний час не висуває підвищених або додаткових вимог. Стан підвищеної готовності може бути викликаний внаслідок завдання творчого характеру 3 високим рівнем новизни, особливим ступенем відповідальності або зумовлений відповідним фізичним самопочуттям. Понижена готовність може 


\section{Питання психології}

бути спричинена надто сильною емотивністю особистості та проявлятися у відвертанні уваги, незібраності, помилкових, хибних діях.

У свою чергу, Ухтомський О., стан готовності до діяльності називає «оперативним спокоєм». Він вважає, що у гарно підготовленого організму за видимою нерухомістю приховується напружена психічна робота. Таким чином, у стані спокою організм утримує нерухомість 3 метою детального розпізнавання середовища. Механізм цього стану спирається на рухливість «нервових процесів», які забезпечують перехід від «оперативного спокою» до термінової дії [13].

Вивченням готовності до екстремальних дій в умовах монотонної роботи займалися Нерсесян Л. та Пушкін В. Під цим поняттям вчені розуміють стан мобілізації всіх психофізіологічних систем людини, які забезпечують швидке та точне реагування на раптову зміну ситуації або умов праці. Поняттям «пильність» вони називають стан готовності, до структури якої входять: образ структури дії, загальний психофізичний стан, психологічну налаштованість особистості на виконання певних дій при аварійній ситуації [8].

На думку Бодрова В. вище перелічені поняття: «передстартовий стан», «стан оперативного спокою», «стан пильності» слід розуміти тотожними до стану тимчасової готовності. На думку автора, такий вид готовності розкриває особливості та вимоги майбутньої ситуації. Її основними рисами $\epsilon$ відносна стійкість, дієвість впливу на процес діяльності, відповідність структури готовності оптимальним умовам досягнення мети.

Необхідно зазначити, що ці представники досліджують проблему психологічної готовності у межах функціонального підходу, в якому готовність розглядається: як певний стан мобілізації всіх психофізіологічних систем особистості, як психологічної умови успішного виконання діяльності; як стан усвідомленої активності, яка спонукає особистість до діяльності; як стан, що передує усвідомленій поведінці. Вона функціонує на тлі загальної активності особистості на фоні якого відбуваються процеси, необхідні для ефективної реалізації різного роду діяльності. Цей підхід характеризується тим, що стан готовності зумовлюється стійкими психічними особливостями властивими конкретній особистості. На стан психологічної готовності мають вплив конкретні умови, у яких відбувається діяльність. Більшість представників даного підходу позиціонують тісний взаємозв'язок функціонального стану і стійкої характеристики особистості. Йдеться про те, що стан готовності це тимчасова готовності, а підготовленість особистості довготривала готовність. Ці два види перебувають у тісному зв'язку між собою. Разом 3 тим, вагомий вклад у вивчення психологічної готовності у межах цього підході внесли Ільїн Е., Тімченко О.

Існує також особистісний підхід (Ананьєв А., Дьяченко М., Кандибович Л., Корольчук М., Леонтьєв О., Платонов К., Рубінштейн С.). представники цього підходу розуміють психологічну готовність як стійке багатоаспектне ієрархізоване утворення особистості, яке містить психологічний, мотиваційний, когнітивний, операційний, емоційно-вольовий, практичний, психофізіологічний, фізичний, оцінюючий компоненти [6]. Психологічну готовність прибічниками цього підходу розуміють як результат підготовки (підготовленості) до певної діяльності. Тобто, особистісний підхід розглядає психологічну готовність як складне особистісне утворення, багатопланову i багаторівневу структуру якостей, властивостей і станів, які в своїй сукупності дозволяють конкретному суб'єкту успішно виконувати діяльність. Цей підхід передбачає вдосконалення психічних процесів, станів і властивостей особистості, які необхідні для ефективної діяльності. Готовність як особистісне утворення, інтегративна стійка характеристика $€$ суттєвим компонентом розвитку особистості в цілому.

На думку Дурай-Новакової К., професійна готовність $є$ не лише наслідком, але й самоціллю професійної підготовки, першою та головною умовою ефективної реалізації можливостей кожної особистості. У своєму дослідженні вчена визначає готовність як складне структурне утворення, провідним значенням якого $є$ позитивні установки, мотиви та усвідомлення цінності роботи. Професійна готовність має безпосередній зв'язок 3 направленістю на професійну діяльність та стійкими установками на працю. До складу готовності входять комплекс професійно-педагогічних знань, навичок і вмінь, а також певний досвід їхнього застосування на практиці.

За версією Рудика П., готовність - це миттєва мобілізація всіх сил особистості, що спрямована на здійснення необхідних дій у 


\section{Питання психології}

відповідний момент [9]. Вчений підкреслює важливість стану готовності, виокремлюючи в ньому роль психічних пізнавальних процесів, що відображають важливі аспекти виконуваної діяльності; емоційних компонентів, які можуть підсилювати чи послаблювати активність людини; вольових компонентів, що сприяють здійсненню ефективних дій стосовно мети; мотивів поведінки. Вагомий та осмислений мотив надає сприятливі умови для швидкого формування готовності.

Максименко С. зазначає, що психологічна готовність до певної діяльності $\epsilon$ істотною передумовою iї цілеспрямованості, регулювання, стійкості та ефективності. Вона містить переконання, погляди, ставлення, почуття, вольові та емоційні якості, знання, навички і вміння, установки, що в сукупності утворює цілісний прояв особистості [5]. Таким чином на думку вищезазначених авторів готовність розглядається як істотна передумова будьякої цілеспрямованої діяльності, ऑiі ефективного здійснення та регуляції.

$\mathrm{y}$ психологічних словниках готовність до дії визначається як «стан мобілізації всіх психофізіологічних систем людини, що забезпечує ефективне виконання певних дій» та «стійкий психологічний стан як результат трудового виховання або тимчасовий як результат психологічної підготовки або психологічної мобілізації в даний період, що визначається наявністю потреби в праці» [1].

Процес психологічної підготовки фахівців до службової діяльності в екстремальних та особливих умовах завжди динамічний і суперечливий. Під час цього процесу формуються, удосконалюються та розвиваються специфічні знання, уміння, навички та якості особистості. Основним завданням психологічної підготовки, на думку Хміляра О. $\epsilon$ формування у військовослужбовця здатності якісно виконувати професійну діяльність в реальних умовах бою. Головною метою $\epsilon$ сформованість психологічної готовності до бою [14].

За даними Сафіна О., у психологічно підготовлених військовослужбовців у бойовій обстановці з'являється характерне бойове збудження, що загострює увагу, пам'ять і мисленнята сприяє активності й цілеспрямованості дій. В своїх працях ВІН детально розглядає проблеми 3 формування довготривалої (особистісний та мотиваційний компоненти) та ситуативної готовності особистості (емоційні), а також описує готовність як цілеспрямоване прагнення особистості, котре виникає в процесі всебічної підготовки і $є$ результатом розвитку особистості, яка оволоділа професією, особливостями певної діяльності [10].

Бітехтіна Л., досліджуючи поведінку службовців військових частин в екстремальних ситуаціях, дійшла висновку, що вона багато в чому зумовлена їхніми індивідуальними особливостями. На сприйняття військовослужбовцем ситуації та оцінки ступеня іï̈ складності, впливають такі чинники: ступінь позитивності самооцінки, впевненості у собі, рівень суб'єктивного контролю, адаптивність, наявність позитивного мислення, очевидність мотивів досягнення успіху та інше. Поведінка військовослужбовця в екстремальній ситуації детермінована рівнем його стресостійкості.

Так, у дослідженнях Осьодла В., під психологічною стійкістю слід розуміти здатність військовослужбовця безвідмовно виконувати функціональну діяльність протягом необхідного часу (оперативна та тривала стійкість) в заданих умовах, зберігаючи психічне здоров'я і боєздатність. Результативність та ефективність діяльності можуть служити прямим показником психологічної стійкості оперативної діяльності [3].

Психологічну готовність фахівця до екстремальних видів діяльності Кокун О. визначає як інтегративне особистісне утворення, яке складається із короткочасної та тривалої готовності і забезпечує його психологічну придатність до діяльності в екстремальних умовах. Дослідник виокремлює тривалу та короткочасну психологічні готовності до діяльності в екстремальних умовах. Перша формується впродовж тривалого часу професійної підготовки та діяльності фахівця i характеризує його потенційну психологічну здатність до виконання різних завдань під час здійснення діяльності в екстремальних умовах. Друга утворюється на основі першої i характеризує наявну на даний період часу (від дня до кількох днів) психологічну здатність до виконання конкретних професійних завдань в таких умовах [2].

В останні роки значну увагу дослідженням психологічної готовності до діяльності військовослужбовців приділяють Алещенко В., Корольчук М, Ягупов В. Під поняттям психологічної готовності військовослужбовців до військовопрофесійної діяльності вчені розуміють 


\section{Питання психології}

націленість та мобілізованість його психіки на подолання майбутніх труднощів, яка забезпечує результативність i якість виконання завдань, адекватно їхньої складності, значущості та важливості.

Висновки: Аналіз сучасних публікацій показав, що автори вкладають у поняття «психологічна готовність» різний зміст. Це пов'язано, із тим, що застосовуються різні підходи: до розуміння психіки, до розуміння сутності готовності, до дослідження різних видів діяльності. Необхідно зазначити, що стан психологічної готовності до діяльності в екстремальних та особливих умовах можна оцінити безпосередньо в процесі виконання конкретного завдання. Враховуючи нестандартні умови несення служби військовослужбовцем, суттєву роль відіграють структурні елементи психологічної готовності. Поділяючи цей підхід, ми вважаємо найбільш обгрунтованою та завершеною позицією авторів, які розглядають психологічну готовність, як сукупність якостей особистості i як психологічний стан. Наприкінці зазначимо, що формування психологічної готовності до професійної діяльності є метою і результатом тривалого процесу професійної та психологічної підготовки фахівців.

\section{Список використаних джерел:}

1. Бродовська В. Й., Патрик І. П., Яблонько В. Я. Тлумачний словник психологічних термінів в українській мові : словник. 2-е видання. Київ : Професіонал, 2005. 224 с.

2. Кокун О. Зміст та структура психологічної готовності фахівців до екстремальних видів діяльності : Проблеми екстремальної та кризової психології : збірник наукових праць. Вип. 7. - Харків: УЦЗУ, 2010.

3. Криворучко П.П. Осьодло В.І. Терещенко Л.Ф. Психологічна робота у миротворчих операціях : Навчальний посібник. - К.: НАОУ ім. Івана Черняховького, 2004. - 284 с.

4. Левитов Н.Д. О психических состояниях человека : М.: Просвещение, 1967. - 343 с.

5. Максименко С. Д. Морально-психологічне забезпечення службової діяльності Прикордонних військ України : Підручник / С. Максименко, Б. Олексієнко. - Хмельницький : Вид-во НАДПСУ, 2001. - 448 с.

6. Морально-психологічне забезпечення підрозділів Збройних Сил України : підручник. [А.О. Кобзар, В.Т. Марценківський, П.М. Слюсаренко та ін.]. - К. : НУОУ ім. Івана Черняховського, 2018. 496 с.

7. Мул С.А. Психологія готовності офіцера-прикордонника до професійної діяльності. - Рукопис. Дисертація на здобуття наукового ступеня доктора психологічних наук за спеціальністю 19.00.01 загальна психологія, історія психології. - Інститут психології імені Г. С. Костюка НАПН України, Київ, 2016.

8. Пушкин, В.Н., Нерсесян Л.С. Железнодорожная психология /В.Н. Пушкин, Л.С. Нерсесян. М.: Транспорт, 1971. - 240 с.

9. Рудик П. А. Психологія : підручник. - М. : ФиС, 2006. - 239 с.

10. Сафін О.Д. Психологія управлінської діяльності командира : Навчальний посібник. Хмельницький: вид-во АПВУ, 1997. - 123 с.

11. Смирнов Б. А, Доглополов Е. В. Психология деятельносты в екстремальних ситуациях : Харків : Гуманітарний центр, 207, - 276 с.

12. Тимченко А. В. Профессиональный стресс работников ОВД Украины (концептуализация, прогнозирования, диагностика и коррекция) : дисс. ... д-ра психол. наук. Харьков : НУВД, 2003. 427 с.

13. Ухтомский, А.А. Физиологический покой и лабильность как биологические факторы : Собрание сочинений в 6 т., 1951.

14. Хміляр О.Ф. Психологічна підготовна солдатів і офіцерів / О. Хміляр / Вісник Національного університету оборони України. - 2013. - № 1 (32). - С. 217-311.

15. Юрченко В. М. Теоретико-методологічні засади дослідження психічних станів людини : дис.. д-ра психол. наук / Інститут психології ім. Г. С. Костюка АПН України. Київ, 2009. 481 с.

\section{References}

1. Brodovcka V. Y., Patryk I. P., Yablonko V. Ya. Tlumachnyi clovnyk pcyxolohichnyx terminiv v ukrainckii movi : clovnyk. 2-e vydannia. Kyiv : Profecional, 2005. 224 c.

2. Kokun O. Zmist ta struktura psykholohichnoi hotovnosti fakhivtsiv do ekstremalnykh vydiv diialnosti : Problemy ekstremalnoi ta kryzovoi psykholohii : zbirnyk naukovykh prats. Vyp. 7. - Kharkiv: UTsZU, 2010.

3. Kryvoruchko P.P. Osodlo V.I. Tereshchenko L.F. Psykholohichna robota u myrotvorchykh operatsiiakh : Navchalnyi posibnyk. - K.: NAOU im. Ivana Cherniakhovkoho, 2004. $-284 \mathrm{~s}$.

4. Levytov N.D. O psykhycheskykh sostoianyiakh cheloveka : M.: Prosveshchenye, 1967. - $343 \mathrm{~s}$.

5. Maksymenko S. D. Moralno-psykholohichne zabezpechennia sluzhbovoi diialnosti Prykordonnykh viisk Ukrainy : Pidruchnyk / S. Maksymenko, B. Oleksiienko. - Khmelnytskyi : Vyd-vo NADPSU, 2001. - 448 s.

6. Moralno-psykholohichne zabezpechennia pidrozdiliv Zbroinykh Syl Ukrainy : pidruchnyk. [A.O. Kobzar, V.T. Martsenkivskyi, P.M. Sliusarenko ta in.]. - K. : NUOU im. Ivana Cherniakhovskoho, 2018. 496 s. 


\section{Питання психології}

7. Mul S.A. Psykholohiia hotovnosti ofitsera-prykordonnyka do profesiinoi diialnosti. - Rukopys. Dysertatsiia na zdobuttia naukovoho stupenia doktora psykholohichnykh nauk za spetsialnistiu 19.00.01 - zahalna psykholohiia, istoriia psykholohii. - Instytut psykholohii imeni H. S. Kostiuka NAPN Ukrainy, Kyiv, 2016.

8. Pushkyn, V.N., Nersesian L.S. Zheleznodorozhnaia psykholohyia /V.N. Pushkyn, L.S. Nersesian. M.: Transport, 1971. $-240 \mathrm{~s}$.

9. Rudyk P. A. Psykholohiia : pidruchnyk. - M. : FyS, 2006. - 239 s.

10. Safin O.D. Psykholohiia upravlinskoi diialnosti komandyra : Navchalnyi posibnyk. - Khmelnytskyi: vyd-vo APVU, 1997. - 123 s.

11. Smyrnov B. A, Dohlopolov E. V. Psykholohyia deiatelnostы v ekstremalnykh sytuatsyiakh : Kharkiv: Humanitarnyi tsentr, 207, - 276 s.

12. Tymchenko A. V. Profeccyonalnыi ctrecc rabotnykov OVD Ukraynы (kontseptualyzatsyia, prohnozyrovanyia, dyahnoctyka y korrektsyia) : dycs. ... d-ra pcyxol. nauk. Xarkov : NUVD, 2003. 427 c.

13. Ukhtomskyi, A.A. Fyzyolohycheskyi pokoi y labylnost kak byolohycheskye faktorb : Sobranye sochynenyi $\mathrm{v} 6$ t., 1951.

14. Khmiliar O.F. Psykholohichna pidhotovna soldativ i ofitseriv / O. Khmiliar / Visnyk Natsionalnoho universytetu oborony Ukrainy. - 2013. - № 1 (32). - S. 217-311.

15. Yurchenko V. M. Teoretyko-metodolohichni zacady doclidzhennia pcyxichnyx ctaniv liudyny : dys.. d-ra pcyxol. nauk/ Inctytut pcyxolohii im. H. C. Koctiuka APN Ukrainy. Kyiv, 2009. 481 c.

\section{Резюме}

Юркова А. И., адъюнкт Наџионального университета обороны Украины им. И. Черняховского

\section{ТЕОРЕТИЧЕСКИЙ АНАЛИЗ ОСНОВНЫХ КОНЦЕПЦИЙ ГОТОВНОСТИ ЛИЧНОСТИ} К ПРОФЕССИОНАЛЬНОЙ ДЕЯТЕЛЬНОСТИ

В статье освещены теоретические подходы $к$ анализу феномена готовности личности $\kappa$ профессиональной деятельности. Приведены аналитический обзор этого понятия разными ученыли. Проанализированы понятия готовности военнослужащиих к действиям в экстремальных условиях. Установлено, что психологическая готовность военных зависят от особенностей нервной системы, жизненного опьта, профессиональных знаний, навыков, мотивации и других особенностей индивида.

Ключевые слова: психологическая готовность; функииональный подход; личностный подход; военнослужашие; военная деятельность.

\section{Summary \\ Yurkova A. I., PhD student University of Defense Ukraine them. I. Chernyakhovsky}

\section{THEORETICAL ANALYSIS OF THE BASIC CONCEPTS OF PERSONALITY READY FOR} PROFESSIONAL ACTIVITY

The article presents theoretical approaches to the analysis of the phenomenon of personal readiness for professional activity. An analytical review of this concept by various scientists is given. The concept of readiness of military personnel to act in extreme conditions is analyzed.

Formulation of the problem. According to its initial characteristics, the professional activity of military personnel is associated with a constant threat to life and health, stress, risk, negative emotional states, high psychophysical stress. Protecting the national interests and security of the country, in turn, puts increased demands on the state of mental health and increases the social significance of the profession of the serviceman. The war in eastern Ukraine has increased the demands for professional and personal responsibility for the results and consequences of the military of the Armed Forces of Ukraine. A prerequisite for a successful start, completion and completion of any activity is readiness for its implementation.

Purpose of the article: theoretical analysis of the basic concepts of readiness of the individual for professional activity.

Research methods: theoretical analysis, generalization.

Conclusions: The analysis of modern publications has shown that the authors put different meaning in the concept of "psychological readiness". This is due to the fact that different approaches have been applied: to understanding the psyche, to understanding the essence of readiness, to exploring different activities. It should be noted that the state of psychological readiness for activity activities in the extreme and especially important can be evaluated directly in the process of completing a specific task. Given the non-standard conditions service, a structural role played by the structural elements of psychological readiness.

In sharing this approach, we consider the most grounded and complete position of authors who consider psychological readiness as a set of personality traits and as a psychological state. Finally, it should be noted that the formation of psychological readiness for professional activity is the purpose and result of a long process of professional and psychological training of specialists.

Key words: psychological readiness; functional approach; personal approach; military; military activity. 